\title{
Expansión tisular en la reconstrucción de defectos craneofaciales
}

\author{
Tissue expansion in the reconstruction of craniofacial defects
}

La expansión tisular constituye una inapreciable herramienta para las reconstrucción del territorio craneofacial y en este sentido es de agradecer a los autores su trabajo, que nos viene a recordar la disponibilidad de dicha técnica, cómo realizarla, sus indicaciones y posibles complicaciones. La reconstrucción de un defecto cutáneo facial obtiene sus mejores resultados estéticos cuando se aporta piel de color y textura similar y cuando se respetan las unidades estéticas de la cara. Cuando el tejido adyacente al defecto es insuficiente para obtener la cantidad necesaria de piel para la reconstrucción los expansores tisulares constituyen una alternativa a tener en cuenta. La expansión cutánea produce un incremento neto de superficie de piel. Si esto se produce sólo por estiramiento o se crea verdaderamente tejido nuevo se ha discutido en diversas publicaciones. Al realizarse la expansión tisular en piel adyacente al defecto, se produce una nueva piel con color y textura similar a la que se ha de reemplazar. Además, si en el diseño del colgajo se preservan los nervios sensitivos cutáneos, persiste la sensibilidad de la piel transferida.

La aparición de dolor, seroma, necrosis por presión, exposición del expansor o infección secundaria son posibles complicaciones.

Entre los inconvenientes de la expansión destacan la necesidad de una cirugía en dos fases, la duración del proceso de expansión con la necesidad de visitas repetidas para hinchar el expansor, las molestias que se producen una o dos horas después de cada expansión, y sobre todo el desagradable aspecto inestético al final de la expansión.

No se deben expandir áreas mal vascularizadas, con infección local, o donde la probabilidad de recurrencia neoplásica es alta.

La expansión se puede emplear para aportar tejido en cualquier zona de la cabeza y el cuello. Se ha empleado para la reconstrucción de la oreja, nariz, labio, piel del cuello... Es particularmente útil para la reconstrucción de la frente y el cuero cabelludo donde la falta de distensibilidad impide el cierre directo de los defectos. También permite trasportar cabello a una zona donde una quemadura o una resección lo ha eliminado. Es especialmente útil en la revisión de cicatrices y en el tratamiento de heridas con infección crónica, al aportar un tejido con el incremento de la vascularización que se asocia a la expansión tisular. La expansión también se ha empleado para corregir distintos patrones de alopecia masculina.

En general, la expansión se realiza hasta conseguir un colgajo que supere entre 30 y $50 \%$ el tamaño del defecto a reparar, pues siempre se produce una cierta contracción del colgajo. Por ello, las revisiones secundarias no se deben realizar hasta pasados de 3 a 6 meses en que el colgajo expandido y transferido haya madurado.

\section{F.J. Alamillos Granados} Médico Adjunto

Servicio de Cirugía Oral y Maxilofacial Hospital Universitario Reina Sofía, Córdoba. España
Tissue expansion constitutes an invaluable tool for+ reconstructions in the craniofacial area and, in this sense, we should be thankful to the authors for their work, as it serves to remind us of the availability of this technique, how to perform it, the indications for it, and possible complications.

On reconstructing facial cutaneous defects the best results are obtained when skin of a similar color and texture is used, and when the aesthetic units of the face are respected. When the tissue next to the defect is insufficient for obtaining the necessary amount of skin for a reconstruction, tissue expansion is an alternative that should be kept in mind.

Tissue expansion produces a net increase in the surface area of the skin. Whether this is produced purely by stretching, or if new tissue is actually formed, has been debated in various publications. On carrying out tissue expansion in skin adjacent to the defect, new skin of a similar texture and color to that which is to be replaced is created. In addition, if in the design of the flap the sensory nerves of the skin are preserved, the sensitivity of the transferred skin will persist.

The appearance of pain, seroma, necrosis through pressure, expander exposure or secondary infection are possible complications.

Among the disadvantages of expansion, of note is the need for surgery in two phases, the duration of the expansion process with the need for repeated visits to inflate the expander, the discomfort that is produced an hour or two after each expansion, and above all the disagreeable inaesthetic aspect at the end of the expansion.

Areas that should not be expanded are those that are not well vascularized, those with local infection, or those where the probability of neoplastic recurrence is high.

Expansion can be used to provide tissue for any area of the head and neck. It has been used for reconstructing ears, noses, lips, and for skin of the neck... It is particularly useful for the reconstruction of the forehead and the scalp where lack of laxity impedes direct closure of the defects. It also allows introducing hair into an area where it has been eliminated through burns or resection. It is especially useful in revision of scars and in treatment of chronically infected wounds, as tissue with increased vascularization connected with tissue expansion is introduced. Expansion has also been used to correct different patterns of male alopecia. 


\section{Bibliografía}

1. Cheney ML. Tissue expansion in the repair of facial defects. En: Facial Surgery. Plastic and Reconstructive. Cheney ML Ed. Williams and Wilkins. Baltimore. 1997;25967.

2. Wieslander JB. Tissue expansion in the head and neck. A 6-year review. Scand J Plast Reconstr Hand Surg 1991;25:47-56.
In general, the expansion is carried out until a flap is achieved that is 30 to $50 \%$ larger than the defect to be repaired, as the flap always contracts to a certain extent. A secondary follow-up should therefore not be carried out until 3 to 6 months have passed, during which time the expanded and transferred flap will have matured. 